\title{
ANALISIS MANAJEMEN KREDIT DALAM UPAYA MEMINIMALKAN KREDIT BERMASALAH (Studi Pada PT. BPR Pantura Abadi Karawang)
}

\author{
Dedi Mulyadi \\ Universitas Buana Perjuangan Karawang \\ Siti Jubaedah \\ Universitas Singaperbangsa Karawang \\ Email: dedimulyadi_krw@yahoo.com
}

\begin{abstract}
Abstak
fenomena kenaikan kredit macet perbankan di Indonesia pada Agustus tahun 2010 jumlah kredit macet sebesar Rp 31,618 triliun, meningkat menjadi Rp 37,932 triliun pada Agustus Tahun 2011. Khusus pada Bank Perkreditan Rakyat (BPR) dari jumlah kredit yang disalurkan pada tahun 2011 sebesar Rp 41,1 triliun dan meningkat menjadi Rp 49,8 triliun tahun 2012 dan tingkat kredit macet mencapai 5,22\% di 2011 menjadi 4,75\% pada akhir 2012. Walaupun terjadi penurunan Non Performing Loan (NPL) akan tetapi fenomena kredit macet tersebut menunjukan bahwa pemberian kredit memiliki risiko tinggi bagi kelangsungan hidup perbankan jika pemberian kredit tidak dikelola dengan baik. Untuk menghidari kredit bermasalah diperlukan suatu manajemen kredit yang merupakan pengelolaan kredit yang baik mulai dari perencanaan jumlah kredit, penentuan suku bunga, prosedur pemberian kredit sampai kepada pengendalian dan pengawasan kredit macet.

Tujuan penelitian ini adalah untuk mengetahui, menanalisis dan mengkaji (1) manajemen kredit yang dilakukan pada PT. BPR Pantura Abadi dalam upaya meminimalkan kredit bermasalah pada PT. BPR Pantura Abadi, (2) faktor-faktor yang menyebabkan kredit bermasalah, (3) Penanganan kredit bermasalah pada PT. BPR Pantura Abadi.Penelitian ini termasuk kedalam penelitian survey, dalam hal ini peneliti terjun langsung kelapangan untuk memperoleh data dengan melakukan wawancara dengan karyawan bagian kredit dan para unsur pimpinan PT. BPR Pantura Abadi dan nasabah yang dipilih. Berdasarkan jenis
\end{abstract}


datanya penelitian ini termasuk penelitian kulitatif, dengan tujuan untuk mengetahui sampai sejauhmana menajemen kredit yang diterapkan dapat meminimalkan kredit bermasalah pada PT. BPR Pantura Abadi. Model analisis dalam penelitian ini menggunakan metode deskriptif untuk membuat gambaran secara sistematis dan faktual dan akurat mengenai fakta-fakta sesuai dengan fenomena yang terjadi.

Hasil dari penelitian ini menunjukan bahwa : (1). PT. BPR Pantura Abadi telah menjalankan meanjemen kredit mulai dari perencanaan, pengorganisasian, pelaksanaan dan pengawasan, (2). Faktor-faktor yang menyebabkan kredit bermasalah adalah disebabkan oleh nasabah yaitu terjadi masalah keluarga, kegagalan usaha dan hal-hal yang tidak diperkirakan (post majeur), (3). Penanganan kredit bermasalah dilakukan dengan Rescheduling, Reconditioning, Restructuring, dan penyerahan jamainan kepada BPR.

Kata kunci : manjemen kredit, faktor-faktor kredit bermasalah, penanganan kredit bermasalah

\section{BAB I PENDAHULUAN}

\subsection{Latar Belakang Penelitian}

Bank Perkreditan Rakyat (BPR) merupakan lembaga perbankan resmi yang diatur berdasarkan Undang-Undang Republik Indonesia No. 7 tahun 1992 tentang Perbankan dan sebagaimana telah diubah dengan Undang-Undang Republik Indonesia No. 10 tahun 1998. Dalam undang-undang tersebut secara jelas disebutkan bahwa ada dua jenis bank, yaitu Bank Umum dan BPR.

Fungsi BPR tidak hanya sekedar menyalurkan kredit kepada para pengusaha mikro, kecil dan menengah, tetapi juga menerima simpanan dari masyarakat. Dalam penyaluran kredit kepada masyarakat Fungsi utama BPR sebagai perantara antara masyarakat kelebihan dana dengan masyarakat kekurangan dana, maka usaha pokok yang dilaksanakan bank adalah kegiatankegiatan pada sektor perkreditan, atau penyaluran dana. Penyaluran kredit merupakan salah satu kegiatan utama bank sebagai lembaga intermediasi. Namun dalam usaha Penyaluran kredit mengandung risiko kegagalan atau 
kemacetan pelunasannya, dalam hal ini nasabah tidak mampu lagi untuk melunasi kreditnya. Oleh karena itu BPR menggunakan prinsip 3T, yaitu Tepat Waktu, Tepat Jumlah, Tepat Sasaran, karena proses kreditnya yang relatif cepat, persyaratan lebih sederhana, dan sangat mengerti akan kebutuhan Nasabah.

Dalam upaya mengantisipasi kredit macet, bank harus menerapkan prinsip kehati-hatian. Dalam memberikan kredit BPR wajib memberikan keyakinan berdasarkan analisis yang mendalam atau itikad dan kemampuan serta kesanggupan nasabah debitur untuk melunasi utangnya atau mengembalikan sesuai dengan perjanjian (Sulhan, 2008:15-16).

Keberhasilan usaha bank diukur dari kelancaran pengembalian kredit yang dicerminkan oleh rendahnya tingkat non performing loan (NPL).

Data Bank Indonesia (BI) menyebutkan hingga Agustus 2011 jumlah kredit macet perbankan naik Rp 1,794 triliun menjadi Rp 37,932 triliun, dari Juli 2011 yang sebesar Rp 36,138 triliun. Jumlah kredit macet ini juga tercatat naik jika dibandingkan dengan Agustus 2010 yang sebesar Rp 31,618 triliun. Disebutkan, jumlah kredit bermasalah (NPL/Non Performing Loan) dari perbankan per Agustus 2011 mencapai Rp 56,26 triliun, naik dari posisi Juli 2010 yang sebesar Rp 54,48 triliun. Rasio NPL perbankan di Agustus 2011 mencapai 2,07\%. Hingga Agustus 2011 total kredit yang dikucurkan perbankan Indonesia mencapai Rp 2.031,61 triliun. Kredit ini naik dibandingkan periode yang sama di 2010 yang nilainya Rp 1.640,43 triliun. (Laporan Bank Indonesia 2011). Adapun dari total kredit itu, sebanyak Rp 1.879,723 triliun masuk kategori lancar. Sementara Rp 10,236 triliun masuk kategori kurang lancar, lalu Rp 8,092 triliun masuk kategori diragukan, dan Rp 37,932 triliun masuk kategori macet.

Sedangkan Kredit yang disalurkan BPR meningkat. Statistik Perbankan Indonesia mencatat, pinjaman yang digelontorkan oleh BPR pada tahun 2011 yakni Rp 41,1 triliun. Ini kemudian meningkat 21,1\% jadi $\mathrm{Rp} 49,8$ triliun tahun 2012. Walaupun rasio kredit macet atau (Non Performing Loan/NPL) BPR bertambah baik. NPL tersebut menurun dari 5,22\% di 2011 menjadi 4,75\% pada akhir 2012. ( Tribunnews.Com, Pebruari 2013), namun kondisi perekonomian dengan rencana kenaikan bahan bakar minyak ditahun 2013 perlu menjadi perhatian secara seksama dalam penyaluran kredit. 
Data di atas menunjukan bahwa pemberian kredit memiliki risiko tinggi bagi kelangsungan hidup perbankan jika pemberian kredit tidak dikelola dengan baik. Untuk menghidari kredit bermasalah diperlukan suatu manajemen kredit yang merupakan pengelolaan kredit yang baik mulai dari perencanaan jumlah kredit, penentuan suku bunga, prosedur pemberian kredit sampai kepada pengendalian dan pengawasan kredit macet (Kasmir, 2000:71-72).

Manajemen perkreditan adalah pengelolaan kredit yang dijalankan oleh bank meliputi perencanaan, pengorganisasian, pelaksanaan, pengawasan sedemikian rupa sehingga kredit tersebut berjalan dengan baik sesuai dengan kesepakatan antara bank dengan debitur (Firdaus, 2009:4).

Berdasarkan uraian di atas, penulis tertarik untuk meneliti mengenai manajemen kredit dalam upaya meminimalkan kredit bermasalah di salah satu Bank Perkreditan Rakyat yang belokasi di Kabupaten Karawang. Judul dalam penelitian ini adalah "Analisis Manajemen Kredit dalam upaya meminimalkan kredit bermasalah (studi kasus pada PT. BPR Pantura Abadi)".

\subsection{Perumusan Masalah}

Berdasarkan latar belakang tersebut selanjutnya dibuat perumusan masalah sebagai berikut :

1. Bagaimana Manajemen Kredit yang dilakukan pada PT. BPR Pantura Abadi dalam upaya meminimalkan kredit bermasalah

2. Faktor-faktor apa saja yang menyebabkan terjadinya kredit bermasalah pada PT. BPR Pantura Abadi.

3. Bagaimana penanganan kredit bermasalah pada PT. BPR Pantura Abadi

\subsection{Tujuan Penelitian}

Berdasarkan pada perumusan masalah di atas penelitian ini bertujuan untuk mengetahui, menganalisis dan mendeskripsikan :

1. Manajemen Kredit yang dilakukan pada PT. BPR Pantura Abadi dalam upaya meminimalkan kredit bermasalah.

2. Faktor-faktor apa saja yang menyebabkan terjadinya kredit bermasalah pada PT. BPR Pantura Abadi.

3. Penanganan kredit bermasalah pada PT. BPR Pantura Abadi. 


\section{BAB II}

\section{TINJAUAN PUSTAKA}

\subsection{Teori yang relevan}

\subsubsection{Pengertian Bank Perkreditan Rakyat (BPR)}

Menurut Hasibuan (2001:38) Bank Perkreditan Rakyat (BPR) adalah bank yang tidak memberikan jasa dalam lalu lintas pembayaran, yang dalam pelaksanaan kegiatan usahannya dapat secara konvensional atau berdasarkan prinsip syariah.

BPR berperan sebagai menghimpun dan menyalurkan dana dari masyarakat. Dengan menggunakan diagram Alir Melingkar perekonomian dapat dijelaskan peranan BPR, yaitu menghimpun dana dari sektor rumah tangga (kelompok masyarakat berpendapatan rendah) dan menyalurkannya kepada sektor perusahaan (kelompok pengusaha ekonomi lemah). Munculnya BPR tersebut menunjukkan bahwa selama ini kelompok masyarakat berpendapatan rendah dan kelompok pengusaha ekonomi lemah belum mampu melakukan akses ke lembaga keuangan yang sudah ada. Peranan lembaga keuangan BPR sebagai penghimpun dan penyalur dana masyarakat diharapkan dapat meningkatkan kesejahteraan masyarakat Indonesia terutama kesejahteraan kelompok masyarakat berpendapatan rendah dan kelompok pengusaha ekonomi lemah (Subagyo, 2002:119).

\subsubsection{Pengertian Kredit}

Kredit berasal dari kata Italia, credere yang artinya kepercayaan, yaitu kepercayaan dari krediturbahwadebiturnyaakan mengembalikan pinjaman beserta bunganya sesuai dengan perjanjian kedua belah pihak. (Hasibuan, 2001:87).

Kredit adalah penyediaan uang atau tagihan yang dapat dipersamakan dengan itu berdasarkan persetujuan atau kesepakatan pinjam meminjam antara bank dengan pihak lain yang mewajibkan pihak peminjam untuk melunasi utangnya setelah jangka waktu tertentu dengan jumlah bunga imbalan atau pembagian hasil keuntungan (UU RI No. 7 Tahun 1992 tentang Perbankan Bab I, Pasal I, ayat 12).

\subsubsection{Pengertian Manajemen Kredit}

Firdaus (2009:4) manajemen kredit adalah pengelolaan kredit yang 
dijalankan oleh bank meliputi perencanaan, pengorganisasian, pelaksanaan, pengawasan sedemikian rupa sehingga kredit tersebut berjalan dengan baik sesuai dengan kesepakatan antara bank dengan debitur.

Pengelolaan kredit adalah kunci utama bagi perbankan nasional untuk tetap bertahan dalam persaingan yang ketat, serta akan memberikan pendapatan atau keuntungan yang diharapkan. Langkah- langkah perbankan diIndonesia agar mencapai kondisi perkreditan yang sehat, yaitu : 1). Perencanaan Kredit; 2). Proses pemberian kredit dan Administrasi kredit; 3). Analisis pemberian kredit; 4). Jenis pembebanan suku bbunga; 5). Pengawasan kredit.

\subsubsection{Prinsip Pemberian Kredit}

Sebelum suatu fasilitas kredit diberikan, maka bank harus merasa yakin bahwa kredit yang diberikan benar-benar akan kembali. Keyakinan tersebut diperoleh dari hasil penilaian kredit sebelum kredit tersebut disalurkan. Kriteria penilaian kredit yang harus dilakukan oleh bank untuk mendapatkan nasabah yang benar-benar menguntungkan dilakukan dengan analisis 5C, 7P dan 3R (Kasmir, 2008).

\section{a. Penilaian kredit dengan metode analisis $5 \mathrm{C}$, yaitu:}

1. Character adalah Sifat atau watak dari orang-orang yang akan diberikan kredit harus dapat dipercaya yang tercermin dari latar belakang nasabah baik latar belakang yang bersikap pekerjaan maupun yang bersifat pribadi seperti: cara hidup atau gaya hidup yang dianutnya, keadaan keluarga, hobi dan sosial standingnya.

2. Capacity adalah Untuk melihat kemampuan calon nasabah dalam membayar kredit yang dihubungkan dengan kemampuannya mengelola bisnis serta kemampuannya mencari laba. Sehingga akan terlihat kemampuannya dalam mengembalikan kredit yang disalurkan.

3. Capital adalah penggunaan modal yang efektif dapat dilihat dari laporan keuangan (neraca dan laporan rugi laba) dengan melakukan pengukuran seperti dari segi likuiditas, solvabilitas, rentabilitas dan ukuran lainnya. Capital adalah untuk mengetahui sumber-sumber pembiayaan yang dimiliki nasabah terhadap usaha yang akan dibiayai oleh bank. 
4. Collateral merupakan jaminan yang diberikan calon nasabah baik yang bersifat fisik maupun non fisik. Jaminan hendaknya melebihi jumlah kredit yang diberikan. Jaminan juga harus diteliti keabsahannya sehingga jika terjadi suatu masalah, jaminan yang dititipkan akan dapat dipergunakan secepat mungkin.

5. Condition adalah kondisi ekonomi pada masa sekarang dan yang akan datang harus dinilai sesuai dengan sektor masing-masing. Prospek usaha dari sektor yang dijalankan oleh nasabah juga harus dinilai. Penilaian prospek bidang usaha yang dibiayai hendaknya memiliki prospek yang baik, sehingga kemungkinan kredit tersebut bermasalah relatif kecil.

\section{b. Penilaian kredit dengan metode analisis $7 \mathrm{P}$ sebagai berikut:}

1. Personality (kepribadian) adalah sifat dan perilaku yang dimiliki calon debitur yang mengajukan permohonan kredit bersangkutan, dipergunakan sebagai bahan pertimbangan pemberian kredit. Jika kepribadiannya baik maka kredit dapat diberikan. Sebaliknya apabila kepribadiannya jelek maka kredit tidak dapat diberikan.

2. Party adalah mengklasifikasikan nasabah dalam klasifikasi tertentu atau golongan-golongan tertentu berdasarkan modal, loyalitas serta karakternya. Sehingga nasabah dapat digolongkan ke golongan tertentu dan akan mendapatkan fasilitas yang berbeda dari bank.

3. Purpose (tujuan) adalah tujuan dan penggunaan kredit oleh calon debitur, apakah untuk kegiatan konsumtif atau sebagai modal kerja. Tujuan kredit ini akan menjadi hal yang menentukan apakah permohonan calon debitur disetujui atau ditolak.

4. Prospect adalah untuk menilai usaha nasabah di masa yang akan datang menguntungkan dan mempunyai prospek atau sebaliknya. Prospect adalah prospek perusahaan dimasa datang,apakah akan menguntungkan (baik) atau merugikan (jelek).

5. Payment (pembayaran) adalah mengetahui bagaimana pembayaran kembali kredit yang diberikan hal ini dapat diketahui jika analisis kredit memperhitungkan kelancaran penjualan dan pendapatan calon debitur 
sehingga dapat memperkirakan kemampuannya untuk membayar kembali kredit tersebtu sesuai dengan perjanjian.

6. Profitability adalah Untuk menganalisis bagaimana kemampuan nasabah dalam mencari laba. Profitability diukur dari periode ke periode apakah akan tetap sama atau akan semakin meningkat, apalagi dengan tambahan kredit yang akan diperolehnya.

7. Protection, tujuannya adalah bagaimana menjaga agar usaha dan jaminan mendapatkan perlindungan. Perlindungan dapat berupa jaminan barang atau orang atau jaminan asuransi.

\section{c. Penilaian Kredit dengan Asas 3 R}

Menurut Hasibuan (2005), ada satu asas lagi yang harus dianalisis sebelum memberikan kredit yaitu asas 3R.

1. Returns adalah penilaian atas hasil yang akan dicapai perusahaan calon debitur setelah memperoleh kredit. Apabila hasil yang diperoleh cukup untuk membayar pinjamannya dan sekaligus membantu perkembangan usaha calon debitur bersangkutan maka kredit diberikan dan begitu pula sebaliknya.

2. Repayment adalah memperhitungkan kemampuan, jadwal, dan jangka waktu pembayaran kredit oleh calon debitur, tetapi perusahaanya tetap berjalan.

3. Risk Bearing Ability adalah memperhitungkan besarnya kemampuan perusahaan calon debitur untuk menghadapi risiko, apakah risikonya besar atau kecil. Kemampuan perusahaan menghadapi risiko ditentukan oleh besarnya modal dan strukturnya, jenis bidang usaha dan manajemen perusahaan bersangkutan. Jika risk bearing ability perusahaan besar maka kredit tidak diberikan dan sebaliknya.

\subsubsection{Pengertian Kredit Bermasalah}

Kredit bermasalah secara umum adalah semua kredit yang mengandung resiko tinggi atau kredit bermasalah adalah kredit-kredit yang mengandung kelemahan atau tidak memenuhi standar kualitas yang telah ditetapkan oleh bank. (Arthesa,dkk, 2006:181). 
Berdasarkan surat keputusan Direksi Bank Indonesia No.31 / 147 / Kep / DIR Tanggal 12 November 1998 tentang kualitas aktiva produktif pasal 6 ayat 1 , membagi tingkat kolektibilitas kredit menjadi :

1. Kredit lancar : Kredit lancar yaitu kredit yang perjalanannya lancar atau memuaskan, artinya segala kewajiban (bunga atau angsuran utang pokok diselesaikan oleh nasabah secara baik).

2. Dalam perhatian khusus (DPK) : Kredit dalam perhatian khusus yaitu kredit yang selama 1-2 bulan mutasinya mulai tidak lancar, debitur mulai menunggak.

3. Kurang lancar (KL) : Kredit tidak lancar yaitu kredit yang selama 3 bulan mutasinya tidak lancar, pembayaran bunga atau utang pokoknya tidak baik. Usaha-usaha pendekatan telah dilakukan tapi hasilnya tetap kurang baik.

4. Diragukan (D) : Kredit diragukan yaitu kredit yang telah tidak lancar dan belum dapat juga diselesaikan oleh debitur yang bersangkutan.

5. Macet (M) : Sudah 6 bulan tidak membayar angsuran.

\subsubsection{Sebab-sebab terjadinya kredit bermasalah}

Beberapa hal yang menjadi penyebab timbulnya kredit bermasalah (Rivai, 2007:478) adalah sebagai berikut:

a. Karena kesalahan Bank : 1). Kurang pengecekan terhadap latar belakang calon nasabah; 2). Kurang tajam dalam menganalisis maksud dan tujuan penggunaan kredit dan sumber pembayaran kembali; 3). Kurang pemahaman kebutuhan keuangan yang sebenarnya dari calon nasabah dan manfaat kredit yang diberikan; 4). Kurang mahir dalam menganalisis laporan keuangan calon nasabah; 5). Kurang lengkap mencantumkan syarat-syarat; 6). Terlalu agresif; 7). Pemberian kelonggaran terlalu banyak; 8). Kurang pengalaman dari pejabat kredit atau account officer; 9). Pejabat kredit atau account officer mudah dipengaruhi, diitimidasi atau dipaksa oleh calon nasabah; 10). Kurang berfungsinya credit recovery officer; 11). Keyakinan yang berlebihan; 12). Kurang mengadakan kunjungan on the spot pada lokasi perusahaan nasabah; 13). Kurang mengadakan kontak dengan nasabah; 14). Pemberian kredit terlalu banyak tanpa disadari

b. Karena Kesalahan Nasabah : 1). Nasabah tidak kompeten; 2). Nasabah tidak atau kurang pengalaman; 3). Nasabah kurang memberikan waktu untuk 
usahanya; 4). Nasabah tidak jujur; 5). Nasabah serakah.

c. Faktor Eksternal : Akibat perubahan pada external environment diidentifikasi penyebab timbulnya kredit bermasalah, seperti perubahan-perubahan political dan lagal environment, deregulasi sector real, financial dan ekonomi menimbulkan pengaruh yang merugikan kepada seorang nasabah. Problem loan akan timbul oleh external environment sebagai akibat gagalnya pengelola dengan tepat mengantisipasi dan menyesuaikan diri dengan perubahan tersebut,(Rivai, 2007: 479) seperti : 1). Kondisi perekonomian;2). Perubahan-perubahan peraturan; 3). Bencana alam.

\subsubsection{Penyelesaian Kredit Bermasalah}

Penyelamatan terhadap kredit macet dilakukan dengan beberapa metode (Kasmir, 2000:103-104) yaitu :

a. Rescheduling, yaitu dengan cara :

1) Memperpanjang jangka waktu kredit : Dalam hal ini debitur diberikan keringanan dalam masalah jangka waktu kredit dari 6 bulan menjadi satu tahun sehingga debitur mempunyai waktu yang lebih lama untuk mengembalikannya.

2) Memperpanjang jangka waktu angsuran hampir sama dengan jangka waktu kredit: Dalam hal ini jangka waktu angsuran kreditnya diperpanjang pembayarannya, misalnya dari 36 kali menjadi 48 kali dan hal ini tentu saja jumlah angsuran pun menjadi mengecil seiring dengan penambahan jumlah angsuran.

b. Reconditioning, dengan cara mengubah persyaratan yang ada seperti :

1) Kapitalisasi bunga, yaitu dengan cara bunga dijadikan hutang pokok.

2) Penundaan pembayaran bunga sampai waktu tertentu.

3) Maksudnya hanya bunga yang dapat ditunda pembayarannya, sedangkan pokok pinjamannya tetap harus dibayar seperti biasa.

4) Penurunansukubunga, maksudnyaagar lebih meringankan beban nasabah. Sebagai contoh jika bunga pertahun sebelumnya dibebankan $17 \%$ diturunkan menjadi $15 \%$. Hal ini tergantung dari pertimbagan bank bersangkutan.

5) Pembebasan bunga, dalam pembebasan suku bunga diberikan kepada 
nasabah dengan pertimbangan nasabah sudah tidak akan mampu lagi membayar kredit tersebut.

c. Restructuring, yaitu dengan cara :

1) Menambah jumlah kredit

2) Menambah equity yaitu dengan menyetor uang tunai dan tambahan dari pemilik

d. Kombinasi : Merupakan kombinasi dari ketiga jenis metode yang di atas.

e. Penyitaan jaminan : merupakan jalan terakhir apabila nasabah sudah benar-benar tidak punya etikad baik atau sudah tidak mampu lagi untuk membayar semua hutang-hutangnya.

\subsection{Penelitian Terdahulu}

Penelitian terdahulu yang digunakan sebagai referensi dalam penelitian ini adalah :

a. Ema Dlauatul Wahyutin (2009) meneliti tentang Analisis Manajemen kredit Guna Menekan Terjadinya Kredit Macet (Studi pada Koperasi"Usaha Tama" Ponggok Blitar). Dengan metode deskriptif memperoleh hasil penelitian bahwa Manajemen kredit dengan cara perencanaan kredit, pengorganisasian, pelaksanaan dan pertanggung jawaban, juga dgn analisis 5C dapat meminimalisir dan menekan terjadinya kredit macet.

b. Azizatul Islamiyah (2009) penelitiannya tentang Analisis Manajemen Kredit Untuk Menurunkan Terjadinya Kredit Bermasalah, metode penelitian yang digunakan deskriptif, hasil penelitiannya adalah Manajemen kredit yang diterapkan sudah mampu dan efektif untuk mengelola kredit dan menurunkan kredit bermasalah dengan menggunakan analisis $5 \mathrm{C}$ dan dengan prinsif manajemen

\section{BAB III}

\section{METODOLOGI PENELITIAN}

\subsection{Metode Penelitian}

Metode penelitian ini berdasarkan eksplanasinya merupakan penelitian deskriptif yaitu suatu metode penelitian yang menggambarkan kejadian atau peristiwa berdasarkan fakta yang ada dan sedang berlangsung. Penelitian ini akan 
menggambarkan manajemen kredit dalam upaya meminimalisir kredit bermasalah pada PT. BPR Pantura Abadi.

\subsubsection{Desain penelitian}

1. Berdasarkan tujuannya penelitian ini merupakan penelitian terapan untuk mengetahui manajemen kredit dalam upaya meminimalkan kredit bermasalah pada PT. BPR Pantura Abadi

2. Berdasarkan metodenya penelitian ini merupakan penelitian evaluasi dengan melakukan analisis manajemen kredit yang dapat meminimalkan kredit bermasalah pada PT. BPR Pantura Abadi

3. Berdasarkan jenis datanya penelitian ini menggunakan data primer hasil wawancara dan observasi serta data sekunder yaitu data laporan keuangan yang berhubungan dengan kredit pada PT. BPR Pantura Abadi

4. berdasarkan model analisis datanya penelitian ini merupakan penelitian deskriptif yang didasarkan pada data-data pelaksanaan manajemen kredit dan data-data kolektabilitas kredit, tingkat Capital adequacy ratio , non performing loan, batas pemberian kredit dan loan to deposit ratio. Pada PT. BPR Pantura Abadi

\subsubsection{Teknik Pengumpulan Data}

a. Wawancara (interview). Dalam penelitian ini peneliti melakukan wawancara dengan pimpinan, manajer kredit dan karyawan bagian kredit PT. BPR Pantura Abadi, serta para debitur yang dipilih.

b. Obsevasi. Dalam penelitian ini observasi dilakukan penulis datang langsung baik ke kantor PT. BPR Pantura Abadi maupun ke tempat debitur yang dipilih.

c. Riset Kepustakaan yaitu dengan mencari literature-literatur yang berhubungan dengan bidang kajian penelitian.

\subsection{Metode Analisis Data}

Nazir (2011 : 63), menjelaskan bahwa Tujuan dari penelitian deskriptif adalah untuk membuat deskripsi, gambaran atau lukisan secara sistematis, faktual, dan akurat mengenai fakta-fakta serta hubungan antar fenomena yang diselidiki, adapun yang dianalisis secara deskriptif dalam penelitian ini adalah manajemen kredit terdiri dari : 
1. Perencanaan kredit.

a. Capital Adequacy Ratio (CAR)

CAR adalah rasio yang memperlihatkan seberapa besar jumlah seluruh aktiva bank yang mengandung resiko (kredit, penyertaan, surat berharga, tagihan pada bank lain) ikut dibiayai dari modal sendiri disamping memperoleh dana-dana dari sumbersumber diluar bank (Almilia, 2005):

$$
\mathrm{CAR}=\frac{\text { modal sendiri }}{A T M R} \times 100 \%
$$

Sumber : Almilia, 2005

Keterangan : ATMR $=$ Aset Tertimbang yang Mengandung Resiko

b. Loan to Deposit Ratio (LDR)

Kredit merupakan total kredit yang diberikan kepada pihak ketiga (tidak termasuk antar bank). Dana Pihak Ketiga mencakup giro, tabungan, dandeposito (tidak termasuk antar bank) (Dendawijaya, 2005):

$$
\text { LDR }=\frac{\text { kredit }}{\text { dana pihak ketiga }} \times 100 \%
$$

Sumber : Dendawijaya, 2005

c. Batasan Maksimum Pemberian Kredit

Berdasarkan Surat Edaran Bank Indonesia Nomor. 11/21/DKBU tentang Batas Maksimum pemberian kredit adalah sebagai berikut :

1) BMPK untuk penyediaan dana kepada pihak terkait adalah $10 \%$ dari modal BPR

2) BMPK untuk penempatan dana antar Bank pada BPR lain pihak tidak terkait adalah $20 \%$ dari modal BPR

3) Penyediaan dana dalam bentuk kredit kepada satu atau lebih peminjam pihak tidak terkait yang merupakan bagian dari kelompok peminjam tidak terkait adalah $30 \%$ dari modal BPR

2. Pengorganisasian kredit.

3. Pelaksanaan kredit

4. Pengawasan kredit. 
Berdasarkan hasil pengawasan kredit akan diketahui efektivitasnya melalui koletibilitas Kredit. Dasar kriteria kolektabilitas adalah seperti dalam tabel 3.3 di bawah ini :

Tabel 3.2

Kriteria Kolektabilitas Kredit PT.BPR Pantura Abadi

\begin{tabular}{|c|c|}
\hline Kolektabilitas Kredit & Umur Piutang \\
\hline Kurang Lancar & $2-3$ bulan \\
\hline Diragukan & $3-6$ bulan \\
\hline Macet & $9-12$ bulan \\
\hline
\end{tabular}

Sumber : PT.BPR Pantura Abadi

Selanjutnya kolektabilitas kredit dihitung berdasarkan prosentase (\%) dengan perhitungan sebagai berikut :

\section{Prosentase kolektabilitas kredit $=$}

$$
\frac{\text { jumlah kredit berdasarkan kriteria }}{\text { jumlah seluruh kredit }} \times 100 \%
$$

Sumber : Dendawijaya, 2005

\section{BAB IV}

\section{HASIL PENELITIAN DAN PEMBAHASAN}

\subsection{Hasil Penelitian}

\subsubsection{Manajemen Kredit yang diterapkan oleh PT. BPR Pantura Abadi}

PT. Bank Pantura Abadi melaksanakan fungsi manajemen dalam pemberian kredit yaitu fungsi perencanaan, fungsi pengorganisasian, fungsi pelaksanaan dan fungsi pengawasan kredit secara berkesinambungan. Langkahlangkahnya adalah :

\section{Perencanaan Kredit}

Dalam perencanaan pemberian kredit PT. Bank Pantura Abadi melakukan evaluasi terlebih dahulu mengenai pengaruh pemberian kredit terhadap kondisi BPR Pantura Abadi secara keseluruhan, acuan kondisi tersebut meliputi :

a. Capital Adequacy Ratio (CAR) adalah rasio antara Modal dan AktivaTertimbang Menurut Risiko (ATMR). Rasio ini digunakan sebagai ukuran kewajiban penyediaan modal minimum atau CAR yang wajib dipenuhi BPR menurut ketentuan Bank Indonesia yaitu 8\%. 
Tabel 4.1

Capital Adequacy Ratio (CAR) PT. BPR Pantura Abadi

\begin{tabular}{|c|c|c|c|}
\hline Tahun & $\begin{array}{c}\text { CAR yang } \\
\text { dicapai }\end{array}$ & $\begin{array}{c}\text { Ketentuan BI } \\
(\text { minimal })\end{array}$ & Keteranagan \\
\hline 2010 & 82,18 & $8 \%$ & \multirow{2}{*}{$\begin{array}{c}\text { Telah memenuhi } \\
\text { kewajiban yang } \\
\text { ditentukan BI }\end{array}$} \\
\hline 2011 & 21,54 & $8 \%$ & nnn \\
\hline 2012 & 14,87 & $8 \%$ &
\end{tabular}

Sumber : PT. BPR Pantura Abadi diolah (2013)

b. Loan to Deposit Ratio (LDR) adalah rasio antara kredit yang diberikan dan Dana Pihak Ketiga (DPK) ditambah Modal sendiri. LDR $\leq 94,75 \%$ akan memberikan kontribusi terhadap peningkatan kesehatan BPR, oleh karena itu, manajemen BPR perlu memelihara LDR yang dapat meningkatkan kesehatan BPR.

Tabel 4.2

Loan to Deposit Ratio (LDR) PT. BPR Pantura Abadi

\begin{tabular}{|c|c|c|c|}
\hline Tahun & $\begin{array}{c}\text { LDR yang } \\
\text { dicapai }\end{array}$ & $\begin{array}{c}\text { Ketentuan BI } \\
\text { (maksimal) }\end{array}$ & Keteranagan \\
\hline 2010 & 34,04 & $94,75 \%$ & Memberi kontribusi \\
\hline 2011 & 78,94 & $94,75 \%$ & \multirow{2}{*}{ terhadap kesehatan BPR } \\
\hline 2012 & 59,04 & $94,75 \%$ & \\
\hline
\end{tabular}

Sumber : PT. BPR Pantura Abadi diolah (2013)

c. Batas Maksimum Pemberian Kredit (BMPK) merupakan salah satu upaya untuk menyebar risiko kredit adalah dengan cara membatasi agar penyaluran kredit tidak terpusat pada debitur - debitur tertentu. BPR akan menyebarkan pemberian kredit dengan mentaati ketentuan BMPK dari BI sehingga pemberian kredit tidak terpusat pada debitur dan/atau kelompok debitur tertentu.

Evaluasi tersebut dilakukan sesuai dengan ketentuan Bank Indonesia, sehingga akan tercapai tujuan dari pemberian kredit yang diberikan kepada debitur yaitu kredit dapat memberikan keuntungan, dapat meminimalisir kredit bermasalah dan pelunasan kredit sesuai kesepakatan. Berdasarkan wawancara dengan bagian pembukuan yaitu ibu Teti Oliawati pada tanggal 10 September 
2013, tidak dapat memberikan data tentang batas maksimum pemberian kredit (BMPK) karena tidak diijinkan oleh Direksi, akan tetapi memberi keterangan bahwa BMPK PT. BPR Pantura Abadi sudah sesuai dengan ketentuan Bank Indonesia Nomor. 11/21/DKBU, karena apabila melanggar akan dikenakan sanksi oleh Bank Indonesia.

\section{Pengorganisasian Kredit}

Dalam upaya mendukung proses pemberian kredit BPR Pantura Abadi membentuk satuan kerja yang terdiri dari : 1). Marketing Officer (Pejabat Marketing); 2). Unit Administrasi Kredit; 3). Pejabat Legal; 4). Komite Kredit. Masing-masing satuan kerja memiliki tugas dan tanggung jawab yang telah ditetapkan oleh direksi.

\section{Pelaksanaan Pemberian Kredit}

Dalam proses pelaksanaan pemberian kredit kepada calon debitur terdapat beberapa tahapan yaitu sebagai berikut :

a. Tahap Awal Pemberian Kredit yaitu Proses pengumpulan data/informasi calon debitur

1) Proses penilaian dan peninjauan jaminan kredit

2) Proses penilaian dan peninjauan jaminan kredit

3) Proses analisa kredit dan penyusunan memorandum kredit dengan memperhatikan 6 C (Character, Capacity, Capital, Collateral, Condition, Cash Flow).

4) Tahap Pengikatan Kredit dan Jaminan

5) Tahap Pencairan Dana Kredit

6) Tahap Monitoring Penggunaan Kredit

\section{Pengawasan Kredit}

Risiko kredit terjadi karena debitur tidak sanggup memenuhi kewajibannya sesuai yang diperjanjikan. Kredit yang produktif akhirnya bisa menjadi kredit bermasalah, oleh sebab itu fungsi pengawasan kredit harus diawali dari upaya yang bersifat pencegahan, yaitu tindakan - tindakan pencegahan sedini mungkin terhadap hal - hal yang dapat merugikan BPR dalam perkreditan atau terjadinya praktik pemberian kredit yang tidak sehat. Langkah-langkah pengawasan yang dilakukan oleh BPT Pantura Abadi adalah : 


\section{a. Pengawasan Internal}

1) Pengawasan untuk pencegahan terjadinya kredit bermasalah dilakukan oleh :

a). Direksi, yaitu setiap pemberian kredit harus mendapatkan persetujuan direksi untuk memastikan prosedur pemberian kredit telah sesuai dengan ketentuan, melakukan penilaian kolektibilitas kredit untuk memastikan penilaian kolektibilitasnya telah sesuai dengan ketentuan yang ditetapkan oleh Bank Indonesia, melakukan penilaian terhadap kualitas aktiva produktif berdasarkan Peraturan Bank Indonesia No. 8/19/2006 Tanggal 5 Oktober 2006, memantau kecukupan jumlah Penyisihan Penghapusan Aktiva Produktif (PPAP) secara rutin, Mengaktifkan fungsi audit internal (SKAI) terhadap semua aspek perkreditan;

b) Marketing Officer, yaitu memantau perkembangan kegiatan debitur termasuk pemantauan melalui kegiatan kunjungan kepada debitur dan memberikan peringatan dini mengenai penurunan kualitas kredit yang diperkirakan mengandung risiko bagi BPR, secara rutin melakukan pembinaan kepada debitur untuk mengarahkan agar debitur dapat memenuhi kewajibannya kepada BPR dengan baik.

2) Pengawasan dalam upaya untuk meningkatkan pemantauan secara dini terhadap kredit - kredit yang akan atau diduga akan menjadi kredit bermasalah, manajemen BPR akan melakukan langkah - langkah pengawasan sebagai berikut :

a) Setiap bulan menyusun daftar atas kredit - kredit yang kolektibilitasnya tergolong Kurang Lancar, Diragukan, dan Macet.

b) Manajemen harus melakukan pengawasan secara khusus terhadap kredit - kredit yang termasuk dalam daftar termaksud diatas dan segera mencari cara-cara penyelesaiannya.

c) Menugaskan Marketing Officer untuk melakukan kunjungan ke tempat debitur bermasalah dan melakukan penagihan secara intensif.

d) Marketing Officer melaporkan hasil kunjungan dan perkembangan kondisi keuangan debitur bermasalah kepada Direksi serta tata cara penyelesaian lebih lanjut atas kredit bermasalah tersebut. 
e) Apabila disadari bahwa kredit yang disalurkan itu menunjukkan tanda tanda akan bermasalah, Marketing Officer bersama unit Administrasi kredit harus segera memeriksa kelengkapan dokumentasi kredit dari debitur yang bersangkutan. Hal ini diperlukan untuk meyakinkan posisi BPR (dari sudut hukum) cukup kuat dalam proses penyelesaian kredit selanjutnya.

\section{b. Pengawasan Ekternal}

Pengawasan Ekternal adalah pengawasan secara ekternal yang dilakukan oleh pihak luar PT. BPR Pantura Abadi dalam hal ini dilakukan oleh Bank Indonesia sebagai otoritas perbankan di Indonesia. Pengawasan oleh Bank Indonesia dilaksanakan melalui audit secara berkala setiap satu tahun satu kali dan sekaligus memberikan pembinaan.

\section{c. Pengawasan Independen}

Pengawasan independen adalah pengawasan yang dilakukan oleh pihak independent, dalam hal ini adalah akuntan publik yang ditunjuk oleh PT. BPR Pantura Abadi. Pelaksanaan audit oleh akuntan publik setiap satu tahun satu kali.

\subsubsection{Faktor-faktor yang menyebabkan Kredit Bermasalah Pada PT. BPR Pantura Abadi}

kredit macet yang terjadi pada PT. BPR Pantura Abadi lebih banyak disebabkan oleh kesalahan debitur yaitu sebagai berikut :

1. Problem keluarga, misalnya perceraian, kematian, sakit yang berkepanjangan.

2. Pemborosan oleh satu anggota keluarga debitur

3. Kegagalan usaha debitur karena tidak mampu mengatur keuangan sehingga menyebabkan kesulitan likuditas.

4. Bagi debitur yang berstatus karyawan, terjadi pemutusan hubungan kerja

5. Terjadi post majeur, kejadian yang tidak diduga seperti debitur atau anggota keluarga debitur mengalami kecelakaan, bencana alam seperti banjir dan puting beliung yang sering terjadi di wilayah Rengasdengklok dan sekitarnya

\subsubsection{Penanganan Kredit Bermasalah Pada BPR Pantura Abadi}


Berdasarkan hasil wawancara dengan direktur PT. BPR Pantura Abadi pada tanggal 13 September 2013 diperoleh keterangan bahwa kredit bermasalah tidak bisa dihindari, oleh sebab itu seluruh pejabat BPR terutama yang terkait dengan aktivitas perkreditan harus memiliki pandangan dan persepsi yang sama dalam menangani kredit bermasalah, yaitu :

1. Manajemen tidak membiarkan atau bahkan menutup - nutupi adanya kredit bermasalah.

2. Manajemen harus mendeteksi secara dini adanya kredit bermasalah atau diduga akan menjadi kredit bermasalah.

3. Penanganan kredit bermasalah atau diduga akan menjadi kredit bermasalah juga harus dilakukan secara dini dan sesegera mungkin.

4. Manajemen tidak melakukan penyelesaian kredit bermasalah dengan cara menambah plafond kredit atau tunggakan - tunggakan bunga di kapitalisasi (plafondering kredit).

5. Manajemen tidak boleh melakukan pengecualian dalam penyelesaian kredit bermasalah, khususnya untuk kredit bermasalah kepada pihak - pihak yang terkait dengan BPR.

Cara - cara yang ditempuh oleh manajemen untuk penyelesaian kredit yang tidak dapat ditagih adalah melakukan pertemuan dengan debitur untuk mencoba mencari jalan keluar yang terbaik bagi debitur maupun BPR. Dari hasil pertemuan tersebut, BPR bisa mengambil salah satu dari langkah - langkah dibawah ini :

1. Rescheduling /penjadualan ulang

Penjadualan ulang yaitu mengubah jadual pembayaran dan atau jangka waktu kredit. Cara ini dilakukan apabila debitur masih mempunyai prospek usaha yang baik, dan kesulitan yang dialami itu sifatnya sementara.

2. Reconditioning/persyaratan ulang

Yaitu perubahan sebagian atau seluruh persyaratan kredit dengan tetap mempertahankan plafond kredit yang ada, misalnya dengan merubah tingkat bunga, jadual angsuran, jangka waktu kredit dan sebagainya. Langkah penyelamatan ini ditempuh sepanjang usaha debitur masih mempunyai prospek yang baik dan masih dapat dipulihkan.

3. Restructuring / restrukturisasi 
Yaitu merubah atau memperbaharui fasilitas kredit antara lain dengan :

a. Konversi seluruh atau sebagian tunggakan bunga menjadi pokok kredit baru.

b. Mencari insvestor yang bersedia mengambil alih usahanya (novasi)

c. Kombinasi antara cara inovasi dan BPR menambah dana kredit baru, disertai dengan penjadualan kembali atau perubahan persyaratan kredit.

4. Kebijakan kombinasi Rescheduling, Reconditioning dan Restructuring

5. Penyerahan jaminan kredit (agunan) kepada BPR untuk dijual sesuai kesepakatan yang dicapai antara BPR dengan debitur. Apabila debitur tidak menunjukkan iktikad baik untuk penyelesaian kreditnya (tidak kooperatif), maka BPR memilih cara penyerahan penagihan kepada pengadilan, tetapi selama ini belum ada penyelesaian kredit dengan cara diserahkan ke pengadilan

\subsection{Pembahasan}

Berdasarkan manajemen kredit yang telah dilakukan oleh PT. BPR Pantura Abadi, selajutnya dapat dilihat efektivitas pelaksanaannya dari kolektibilitas kredit didasarkan kepada kreteria kolektibilitas yaitu sebagai berikut:

\section{Tabel 4.3}

Kriteria Kolektibilitas Kredit

(SK BI No.31/147/KEP/DIR dan SE BI No,31/10/UPPB tanggal 12 Nopember 1998)

\begin{tabular}{|l|l|l|}
\hline Kriteria & Tunggakan & Lamanya \\
\hline Lancar & Tiadak ada tunggakkan & - \\
\hline Dalam perhatian khusus & Pokok atau bunga & s/d 90 hari \\
\hline Kurang Lancar & Pokok dan atau bunga & 90 s/d 180 hari \\
\hline Diragukan & Pokok dan atau bunga & 180 s/d 270 hari \\
\hline Macet & Pokok dan atau bunga & 270 hari \\
\hline
\end{tabular}

Sumber : Bank Indonesia, (diolah penulis, 2013)

Adapun kolektibilitas kredit PT. BPR Pantura Abadi mulai dari tahun 2010 sampai dengan tahun 2012 adalah sebagai berikut : 
Tabel 4.4

Kolektabilitas Kredit PT. BPR Pantura Abadi (000)

\begin{tabular}{|c|c|c|c|}
\hline \multirow{2}{*}{ Kolektibilitas } & \multicolumn{3}{|c|}{ Tahun } \\
\cline { 2 - 4 } & $\mathbf{2 0 1 0}$ & $\mathbf{2 0 1 1}$ & $\mathbf{2 0 1 2}$ \\
\hline Lancar & 3.226 .895 & 18.576 .404 & 26.656 .679 \\
\hline Dalam Perhatian Khusus & - & - & - \\
\hline Kurang lancar & 15.620 & 3.337 & 888.542 \\
\hline Diragukan & 7.400 & - & 74.098 \\
\hline Macet & 34.027 & 121.254 & 283.293 \\
\hline Jumlah kredit & $\mathbf{3 . 2 8 3 . 9 4 2}$ & $\mathbf{1 8 . 7 0 0 . 9 9 5}$ & $\mathbf{2 7 . 9 0 2 . 6 1 2}$ \\
\hline
\end{tabular}

Sumber : PT. BPR Pantura Abadi, 2013

Sedangkan secara persentase kolektibilitas kredit PT. BPR Pantura Abadi adalah sebagai berikut :

Tabel 4.5

Persentase Kolektabilitas KreditPT. BPR Pantura Abadi

\begin{tabular}{|c|c|c|c|c|c|}
\hline Tahun & $\begin{array}{c}\text { Lancar } \\
(\boldsymbol{\%})\end{array}$ & $\begin{array}{c}\text { Kurang } \\
\text { Lancar }\end{array}$ & $\begin{array}{c}\text { Diragukan } \\
(\boldsymbol{\%})\end{array}$ & $\begin{array}{c}\text { Macet } \\
(\boldsymbol{\%})\end{array}$ & $\begin{array}{c}\text { Non Performing } \\
\text { Loan }\end{array}$ \\
\hline 2010 & 98,26 & 0,48 & 0,22 & 1,04 & 1,74 \\
\hline 2011 & 99,33 & 0,02 & - & 0,65 & 0,67 \\
\hline 2012 & 95,55 & 3,18 & 0,26 & 1,01 & 4,45 \\
\hline
\end{tabular}

Sumber : PT. BPR Pantura Abadi (diolah penilis), 2013

Berdasarkan data pada tabel 3.2 dan 3.3 di atas menunjukan bahwa dari jumlah kredit yang diberikan kepada debitur pada tahun 2009 sebesar Rp. 3.283.942.000 terdapat kredit dengan kategori lancar sebesar Rp. 3.226.895.000 atau $98,26 \%$, dan yang dinyatakan kredit bermasalah sebesar $1,74 \%$. Seiring dengan penambahan modal saham dari Rp. 2.000.000.000,- (dua milyar rupiah) pada tahun 2010 menjadi Rp. 6.000.000.000,- (enam milyar rupiah) pada tahun 2011, oleh karena itu jumlah kredit yang diberikan kepada debitur pada tahun 2011 meningkat signifikan menjadi Rp. 18.700.995.000,- dengan tingkat kredit lancar sebesar Rp. 18.576.404.000,-- sedangkan yang dinyatakan kredit bermasalah sebesar 0,67\%. Pada tahun 2012 kredit yang diberikan mengalami peningkatan pula yaitu sebesar Rp. 27.902.612.000,- dengan kredit lancar sebesar Rp. 26.656.679.000,- dengan tingkat kredit bermasalah sebesar 4,45\%. Walaupun terjadi kenaikan persentase kredit bermasalah (non Performing Loan) dari tahun 
2011 ke tahun 2012 sebesar 3,78\% akan tetapi masih dalam ambang batas wajar karena secara keseluruhan kredit bermasalah rata-rata di bawah $5 \%$ dari seluruh pinjaman yang diberikan, sedangkan untuk kredit macet saja setiap tahun tidak melebihi $2 \%$, hal ini menunjukan bahwa manejemen kredit yang dilakukan oleh PT. BPR Pantura Abadi sudah sangat efektif.

\section{BAB V}

\section{KESIMPULAN DAN SARAN}

\subsection{Kesimpulan}

Bedasarkan hasil penelitian, penulis membuat kesimpulan sebagai berikut :

1. Manjemen kredit yang dilaksanakan oleh PT. BPR Pantura Abadi dalam upaya meminimalkan kredit bermasalah dengan melaksanakan fungsi manajemen yaitu: perencanaan, pengorganisasian, pelaksanaan dan pengawasan

2. Factor-faktor yang menyebankan kredit bermasalah disebabkan oleh kesalahan debitur biasanya problem keluarga, pemborosan, kegagalan usaha, pemutusan hubungan kerja bagi debitur yang berstatus karyawan dan terjadinya post majeur atau kejadian yang tak diduga seperti bencana alam.

3. Penanganan kredit bermasalah pada PT. BPR Pantura Abadi adalah melakukan resceduling, Reconditioning dan Restructuring atau kombinasi dari ketiga kebijakan tersebut. Langkah berikutnya penjualan aset debitur yaitu Upaya ini dilakukan dengan cara memberikan kesempatan kepada debitur untuk menjual asetnya oleh debitur yang bersangkutan bersamasama pihak bank dan nilai penjualan akan dipakai untuk melunasi kreditnya sedangkan sisanya dari nilai penjualan diberikan kepada nasabah.

\subsection{Saran-saran}

penulis dapat memberikan saran-saran sebagai berikut :

1. Prinsip kehati-hatian dalam pemberian kredit harus tetap dilaksanakan secara konsinten dan menjadi komitmen seluruh pimpinan dan karyawan.

2. Pembinaan terhadap debitur harus dilakukan secara berkesinambungan sejak debitur mendapat pinjaman dengan memberikan pemahaman tentang 
dinamika bisnis yang ditekuni debitur dan tentang pengelolaan uang. Selanjutnya komunikasi yang intensif terus dilakukan.

3. Mengadakan pertemuan dengan debitur untuk membicarakan jalan keluar penyelesaian kredit bermasalah tersebut dengan menawarkan alternatifalternatif penyelesaian, hal ini diharapkan terus dilakukan dengan konsiten dan didasari win-win solutions sehingga tidak ada pihak yang merasa dirugikan.

\section{DAFTAR PUSTAKA}

Arthesa, Ade \& Edia Hardiman. 2006. Bank \& Lembaga Keuangan Bukan Bank. PT Indeks, Jakarta.

Dendawijaya, Lukman, 2005. Manajemen Perbankan, Edisi Kedua, Cetakan. Kedua, Ghalia Indonesia, Bogor

Kasmir, 2000. Manajemen Perbankan, Penerbit PT. Raja Grafindo Persada, Jakarta.

Kasmir. 2008. Bank dan Lembaga Keuangan Lainnya. Edisi Revisi 2008. Jakarta: PT. RAJAGRAFINDO PERSADA.

Firdaus, Rachmat dan Maya Ariayanti, 2009. Manajemen Perkreditan Bank Umum, Penerbit ALFABETA, Bandung.

Hasibuan, Malayu, 2001. Dasar-Dasar Perbankan, Penerbit Bumi Aksara, Jakarta.

Hasibuan, Malayu, 2005. Dasar-Dasar Perbankan, Penerbit Bumi Aksara, Jakarta.

Islamiyah, Azizatul, 2009. Analisis Manajemen Kredit Untuk Menurunkan Terjadinya Kredit Bermasalah studi kasus pada PT. BPR Gunung Ringgit Malang, Skripsi Jurusan Manajemen Fakultas Ekonomi UIN Malang

Rivai, Veithzal \& Andria Permata Veithzal, 2007. Credit Management Handbook, PT RajaGrafindo Persada, Jakarta

Nazir. 2011. Metode Penelitian. Ghalia Indonesia. Bogor

Subagyo, dkk, 2002. Bank dan Lembaga Keuangan Lainnya, Edisi ke-2, Penerbit STIE, Yogyakarta. 
Wahyutin, Ema Dlauatul, 2009. Analisis Manajemen kredit Guna Menekan Terjadinya Kredit Macet (Studi pada Koperasi "Usaha Tama" Ponggok Blitar), Skripsi Jurusan Manajemen Keuangan Fakultas Ekonomi UIN Malang

Almilia, Luciana Spica, dan Winny Herdiningtyas, 2005. "Analisa Rasio Camel terhadap Prediksi Kondisi Bermasalah pada Lembaga Perbankan Periode 2000-2002”. Jurnal Akuntansi dan Keuangan. Volume 7 Nomor 2, STIE Perbanas, Surabaya, hal 12. 